NREL/MK--411-4973

DE92 010597

THE

\title{
PHOTOVOLTAIC MANUFACTURING TECHNOLOGY PROJECT:
}

PHASE 1 SUBCONTRACTORS

Dabs

001091992

$x$ 


\title{
On September 16, 1991 the Solar Energy Institute was designated a national laboratory, and its name was changed to the National Renewable Energy Laboratory.
}

\section{NOTICE}

This report was prepared as an account of work sponsored by an agency of the United States government. Neither the United States government nor any agency thereof, nor any of their employees, makes any warranty, express or implied, or assumes any legal liability or responsibility for the accuracy, completeness, or usefulness of any information, apparatus, product, or process disclosed, or represents that its use would not infringe privately owned rights. Reference herein to any specific commercial product, process, or service by trade name, trademark, manufacturer, or otherwise does not necessarily constitute or imply its endorsement, recommendation, or favoring by the United States government or any agency thereof. The views and opinions of authors expressed herein do not necessarily state or reflect those of the United States government or any agency thereof.

\author{
Printed in the United States of America \\ Available from: \\ National Technical Information Service \\ U.S. Department of Commerce \\ 5285 Port Royal Road \\ Springfield, VA 22161
}

Price: Microfiche A01

Printed Copy $\mathrm{A03}$

Codes are used for pricing all publications. The code is determined by the number of pages in the publication. Information pertaining to the pricing codes can be found in the current issue of the following publications which are generally available in most libraries: Energy Research Abstracts (ERA); Government Reports Announcements and Index (GRA and 1); Scientific and Technical Abstract Reports (STAR); and publication NTIS-PR-360 available from NTIS at the above address. 


\section{DISCLAIMER}

Portions of this document may be illegible electronic image products. Images are produced from the best available original document. 


\section{THE PHOTOVOLTAIC MANUFACTURING TECHNOLOGY PROJECT: PHASE I SUBCONTRACTORS}

The Phase 1 portion of the Photovoltaic Manufacturing Technology (PVMaT) Project, the problem identification phase, was completed in mid-1991. This work involved competitive bidding that was open to any U.S. firm with existing manufacturing capabilities, regardless of material or module design. In early 1991, subcontracts were awarded to 22 of approximately 40 bidders. Each subcontract was funded at a level of up to $\$ 50,000$ and a duration of three months (see Table 1 ).

The problems identified by the research in this phase of the program represent opportunities for industrial participants to improve their manufacturing processes, reduce manufacturing costs, increase product performance, or develop a foundation for scaling up U.S.-based manufacturing plant capacities. Many of these opportunities have since been detailed in the approaches that these organizations suggested for Phase 2 (the problem solution phase) research and development (R\&D). It is not anticipated that any additional Phase 1 solicitation will be issued because Phase 1 was intended to help the U.S. Department of Energy (DOE) characterize the status and needs of the U.S. photovoltaic (PV) industry and encourage the industry to examine and prioritize required manufacturing line improvements.

Table 1. PVMat Phase 1 Subcontractors

\begin{tabular}{lllll}
\hline Subcontractor, Location & Subcontract \# & Funding & Prin. Invest. \\
\hline Spire Corporation, Bedford, MA & XC-1-10057-1 & & $\$ 49,843$ & S.J. Hogan \\
Astropower Inc, Newark, DE & XC-1-10057-2 & $\$ 50,000$ & W.R. Bottenberg \\
Solarex Corp., Rockville, MD & XC-1-10057-3 & $\$ 49,974$ & J. Wohlgemath \\
Siemens Solar Industries, Camarillo, CA & XC-1-10057-4 & $\$ 46,181$ & C. Eberspacher \\
Westinghouse Electric Corp., Pittsburgh, PA & XC-1-10057-5 & $\$ 49,992$ & R. Rosey \\
Silicon Energy Corp., Chatsworth, CA & XC-1-10057-6 & $\$ 49,602$ & M. Stern \\
Glasstech Solar Inc., Golden, CO & XC-1-10057-7 & $\$ 49,913$ & S. Brown \\
Global Photovoltaic Spec., Canoga Park, CA & XC-1-10057-8 & $\$ 47,800$ & H. Somberg \\
Alpha Solarco Inc., Cincinnati, OH & XC-1-10057-9 & $\$ 48,380$ & E.C. Schmidt \\
Photon Energy, Inc., El Paso, TX & XC-1-10057-10 & $\$ 49,500$ & S.P. Albright \\
Energy Conversion Devices, Troy, MI & XC-1-10057-11 & $\$ 50,000$ & M. Izu \\
Mobil Solar Energy Corp., Billerica, MA & XC-1-10057-12 & $\$ 50,000$ & J. Kalejs \\
Entech Inc., Dallas, Texas & XC-1-10057-13 & $\$ 49,940$ & M.J. O'Neill \\
Boeing Aerospace, Seattle, WA & XC-1-10057-14 & $\$ 49,862$ & W.J. Stanbery \\
Solar Kinetics, Inc., Dallas, TX & XC-1-10057-15 & $\$ 48,290$ & S.T. Saifee, \\
Chronar Corp., Lawrenceville, NJ & XC-1-10057-16 & $\$ 49,080$ & J. Macneil \\
Crystal Systems Inc., Salem, MA & XC-1-10057-17 & $\$ 50,000$ & F. Schmid \\
Iowa Thin Films Tech., Ames, IA & XC-1-10057-18 & $\$ 47,827$ & D.P. Grimmer \\
Solar Cells Inc., Toledo, OH & XC-1-10057-19 & $\$ 38,034$ & J.L. Brown \\
Kopin Corporation, Taunton, MA & XC-1-10057-20 & $\$ 50,000$ & R.P. Gale \\
Solar Engineering Appl, San Jose, CA & XC-1-10057-21 & $\$ 50,000$ & N. Kaminar \\
Spectrolab Inc., Sylmar, CA & XC-1-10057-22 & $\$ 35,169$ & D.R. Lillington \\
& & &
\end{tabular}

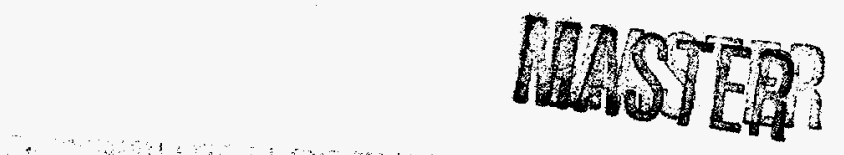


Phase 1 subcontracted research included five subcontractors working on flat-plate crystalline silicon technology, eleven working on flat-plate thin-film modules (one in thin-film crystalline silicon, six in amorphous silicon, and four in polycrystalline thin films), six working on concentrator systems, and two working on general equipment/production options. (Two of the participants each worked in two areas)

\section{Flat-Plate Crystalline Silicon Modules}

Crystalline silicon is the most common semiconductor material used in commercial PV devices. With PVMaT Phase 1 support, five companies detailed their problems in this technology. This group of crystalline silicon research organizations includes Mobil Solar Energy Corp. of Billerica, Massachusetts; Crystal Systems Inc. of Salem, Massachusetts; Westinghouse Electric Corp. of Pittsburgh, Pennsylvania; Solarex Corp. of Rockville, Maryland; and Siemens Solar Industries of Camarillo, California.

Mobil Solar Energy Corp. is a major manufacturer of crystalline-silicon modules using the edge-defined film-fed growth (EFG) method (shown in Figure 1). Mobil Solar is currently supplying a 180-kW (alternating current) array to Photovoltaics for Utility Scale Applications (PVUSA), a major demonstration project in California. Mobil Solar research under Phase 1 of PVMaT identified several problem areas that

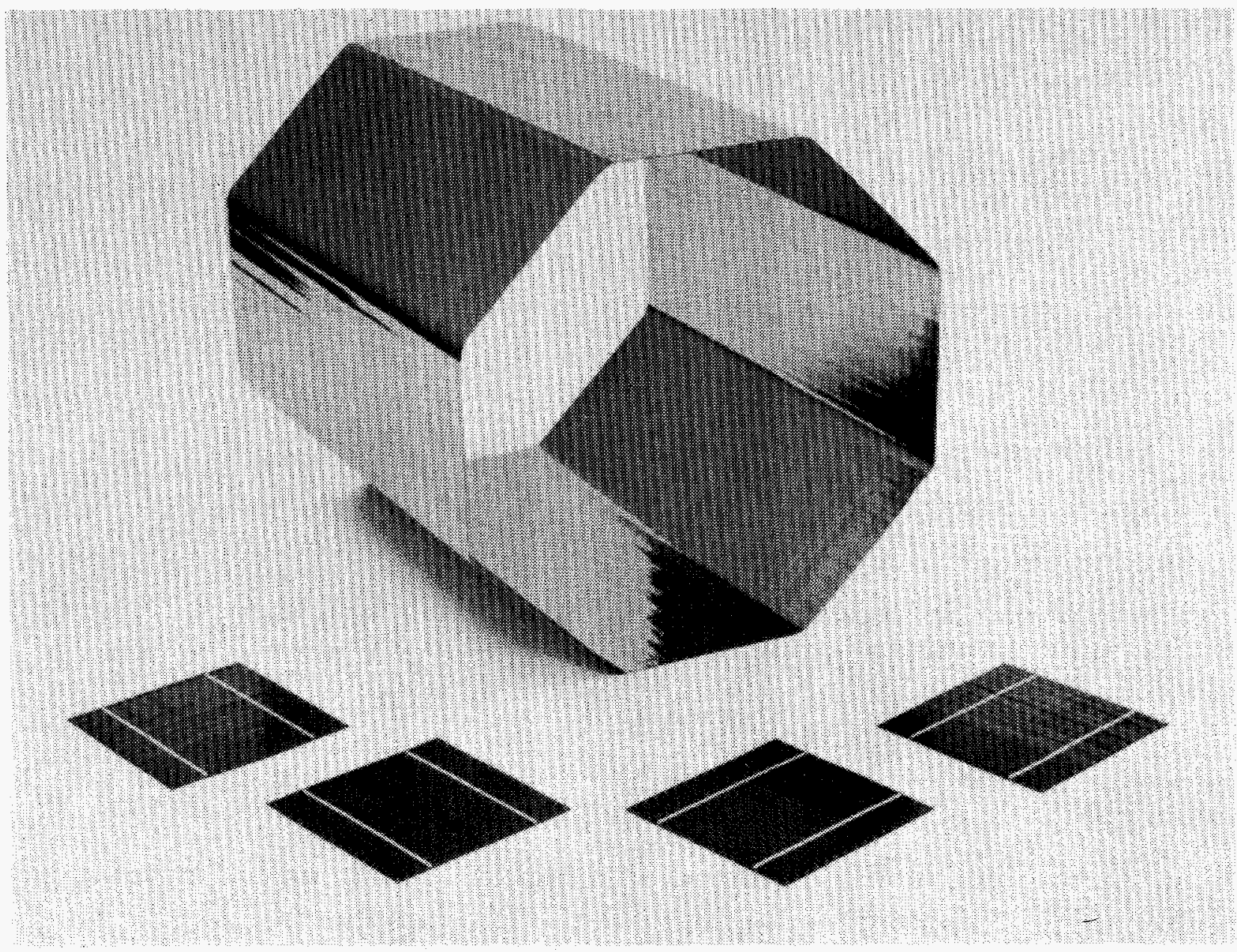

Figure 1. Crystalline silicon grown by Mobil Solar Energy Corp., and the resulting solar cells 
can be addressed to improve their process and reduce their silicon material usage by $50 \%$. Among these are reducing material usage by decreasing wafer thickness to an 8-mil (200-um) thickness, increasing laser cutting throughput, and improving the wafer mechanical quality.

Crystal Systems Inc. is a manufacturer of crystalline-silicon ingots, bars, and wafers. Crystal Systems research under Phase 1 of PVMaT identified several problem areas for improving their process. Among these are the optimization of the fixed abrasive slicing technique (FAST). This will allow for a reduction in slicing costs and an improvement in their material utilization, thus reducing wafer cost.

Westinghouse Electric Corp. is the leading manufacturer of dendritic-web solar cells. Westinghouse is working on reducing material and process costs through their dendritic web process. Westinghouse research under Phase 1 of PVMaT identified several problem areas for improving their process. Among these are increasing the growth rates, average crystal area, and productive furnace time; using stacked diffusion; manufacturing larger cells and modules; increasing module efficiency by $1.4 \%$ absolute using surface passivation, improved antireflective coatings, and cell texturization; and optimizing module design using the bifacial conversion characteristics of dendritic-web solar cells.

Solarex Corp. currently manufactures both polycrystalline silicon cells and thin-film, single-junction, amorphous silicon (a-Si) modules and is described in the next section.

The fifth company working with crystalline silicon is Siemens Solar Industries. They are currently the world's largest producer of PV systems with products including single-crystal silicon modules. Future products are expected to include thin-film copper indium diselenide $\left(\mathrm{CuInSe}_{2}\right)$ modules. Siemens research under Phase 1 of PVMaT identified several problem areas for improving their process. These include improvements in Czochralski crystalline-silicon growth, existing wafer sawing technology, and cell processing and module fabrication.

\section{Flat-Plate, Thin-Film Modules}

Modules made of thin-film materials have inherent cost advantages, including the use of less semiconductor material and integrated manufacturing for cells and modules. Prices for a-Si modules are comparable to those for crystalline silicon. Other promising thin-film technologies-such as CuInSe ${ }_{2}$, cadmium telluride $(\mathrm{CdTe})$, thin-film silicon, and gallium arsenide (GaAs) - are rapidly approaching commercialization.

Eleven U.S. companies have received PVMaT Phase 1 support to identify potential cost reductions for thin-film module manufacturing: one is working in thin-film crystalline silicon, six are concentrating on a-Si, and four have focused on polycrystalline thin films.

AstroPower Inc. is the only manufacturer of thin-film crystalline-silicon solar cells. AstroPower research under Phase 1 of PVMaT identified several problem areas for improving their process. These include improving the production rate and quality of their proprietary silicon film, improving cell efficiency, reducing material cost, reducing labor cost through automation, and increasing production capacity.

The six a-Si manufacturing and R\&D organizations include Solarex Corp. of Rockville, Maryland; Glasstech Solar Inc. of Golden, Colorado; Iowa Thin Films Technologies Inc. of Ames, Iowa; Energy Conversion Devices (ECD) of Troy, Michigan; Silicon Energy Corp. of Chatsworth, California; and Chronar Corp. of Lawrenceville, New Jersey. Glasstech Solar Inc. and Chronar Corp. have now closed their manufacturing facilities and are no longer functional. Their interests are summarized here for completeness. 
Solarex Corp. presently manufactures both polycrystalline silicon cells and thin-film, single-junction, a-Si modules. Solarex research under Phase 1 of PVMaT identified several problem areas for improving their a-Si manufacturing process. Among these are improving module efficiency (from the present $5 \%$ for single-junction modules) by introducing multijunction devices into the module assembly line, using materials more efficiently via increased process yield, reducing labor content via automation, and reducing material costs, particularly those of framing.

Glasstech Solar Inc. was a manufacturer of single-junction a-Si modules. Glasstech used a proprietary glass-in/panel-out concept for in-line processing of $40 \mathrm{~cm} \times 120 \mathrm{~cm}$ a-Si modules. Glasstech research under Phase 1 of PVMaT identified several problem areas for improving their process. Among these are the incorporation of a vertical, double-sided reactor, enhanced electrode and gas flow designs; improved back contacts and tin-oxide layers; and improved module designs.

Iowa Thin Film Technologies produces monolithic a-Si modules on a continuous polymer substrate using automated processing (shown in Figure 2). Iowa Thin Film research under Phase 1 of PVMaT identified several problem areas for improving their process. Among these are developing a roll-to-roll deposition

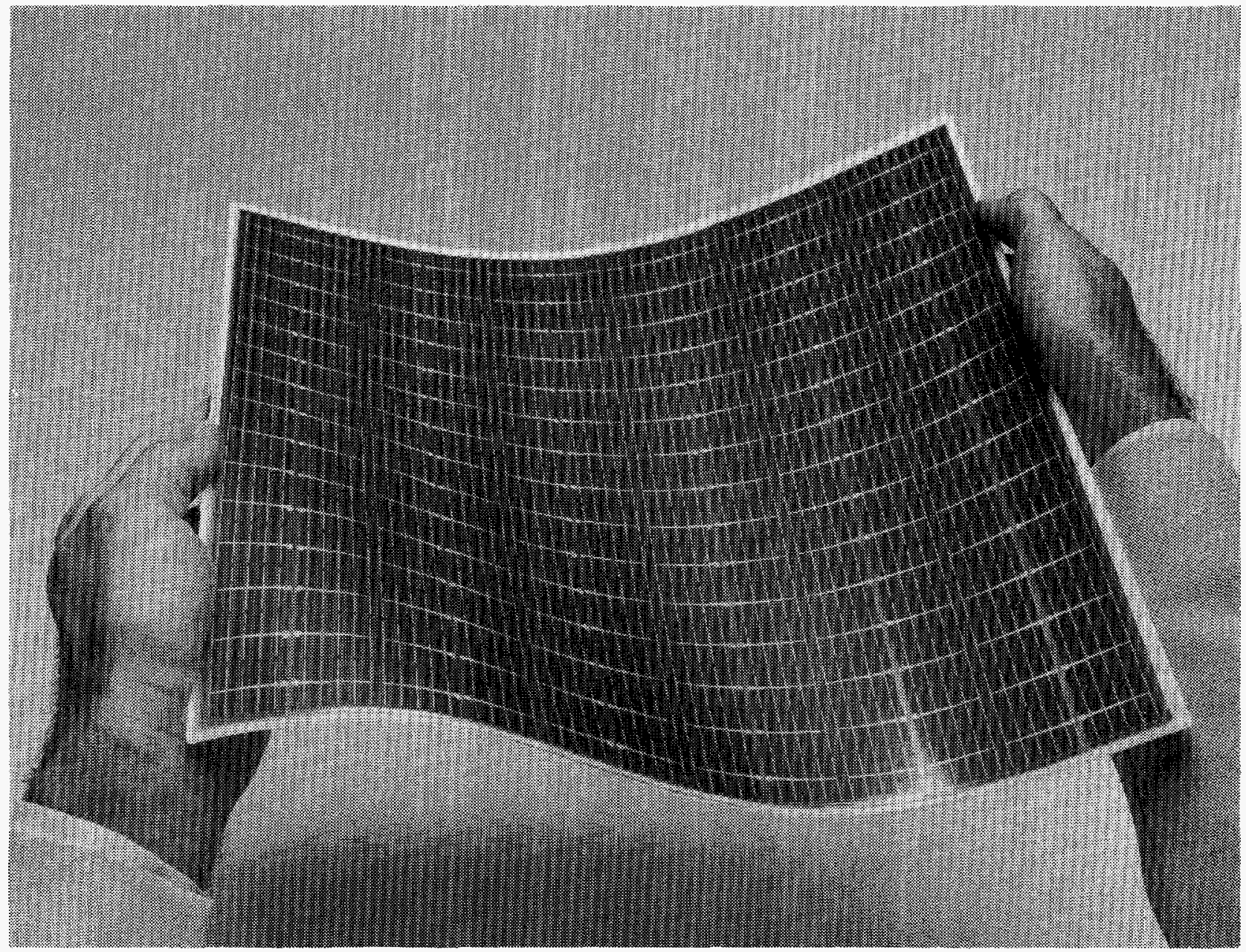

Figure 2. Flexible, amorphous silicon module produced by Energy Conversion Devices 


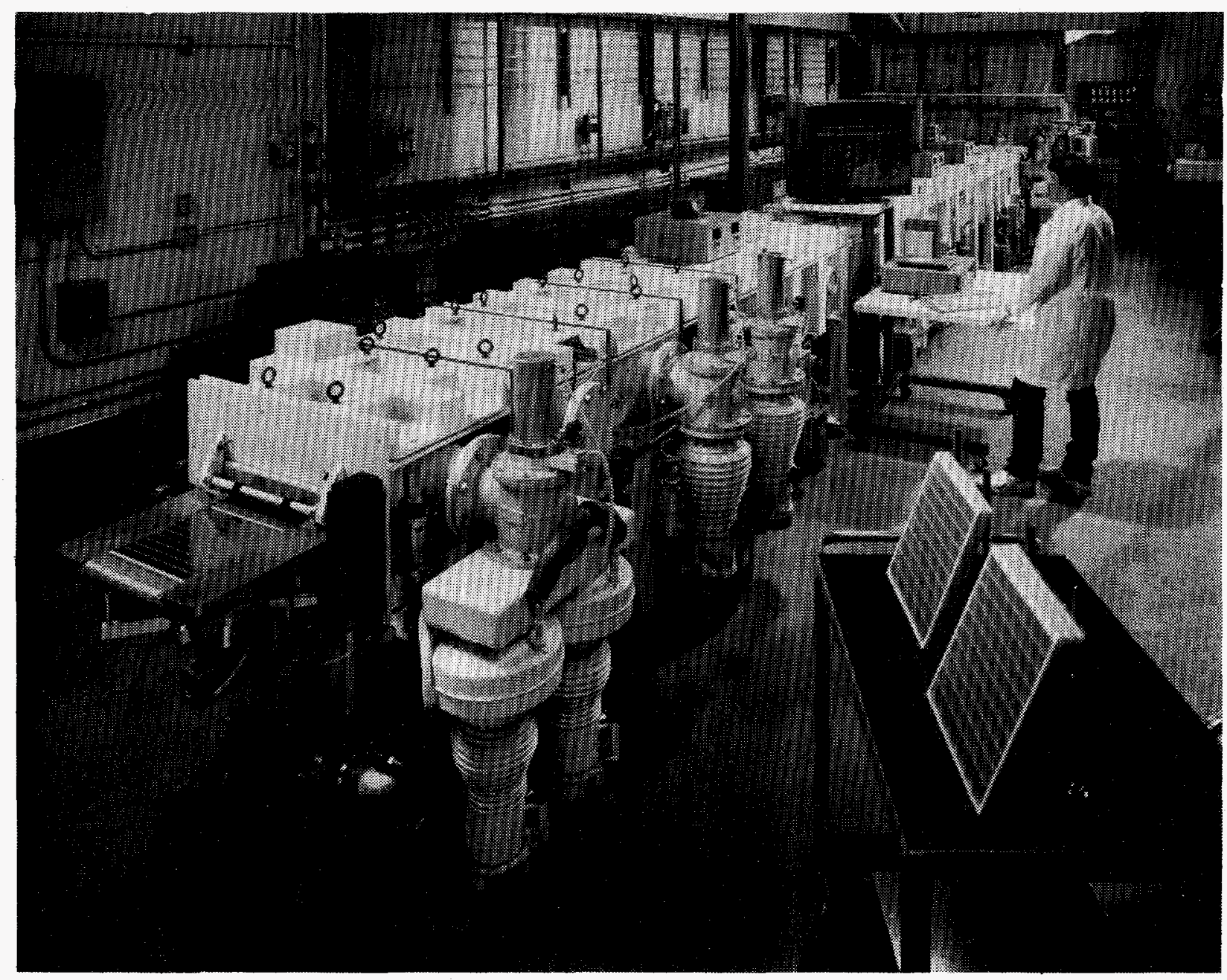

Figure 3. Utility Power Group's manufacturing line

capability for the a-Si and $\mathrm{ZnO}$ layers, developing screen-printable etching steps for the top conducting contact layer, and reducing the cost of the substrate material.

ECD manufactures continuous, roll-to-roll, tandem-junction, a-Si alloy devices. The roll-to-roll process produces a complete solar cell structure on flexible stainless-steel webs 1000 feet long and 14 inches wide. ECD research under Phase 1 of PVMaT identified several problem areas for improving their process. Among these are incorporating lower-band-gap material to improve conversion efficiencies and stability, incorporating proprietary microwave plasma chemical vapor deposition manufacturing technology for highproduction throughput and higher gas utilization, and reducing the costs of materials and assembly labor through new product design and automation.

Silicon Energy Corp. manufactures multiple-junction thin-film a-Si modules and is doing business as the Utility Power Group. The company has a $300 \mathrm{~kW} / \mathrm{yr}$ production facility dedicated to intemal R\&D activities and various DOE PV projects. Utility Power Group's research under Phase 1 of PVMaT identified several problem areas for improving their process. Among these are optimizing the automation of their manufacturing line (shown in Figure 3), improving and reducing the material required for encapsulation, and introducing real-time processing and quality control to their production line. 
The sixth company working with a-Si is Chronar Corp., a manufacturer of thin-film a-Si devices. Chronar research under Phase 1 of PVMaT identified several problem areas for improving their process. Among these is the implementation of automated manufacturing to achieve large cost reductions.

Four organizations have focused on polycrystalline thin films. This group of research organizations includes Siemens Solar Industries of Camarillo, California; Boeing Aerospace and Electronics of Seattle, Washington; Photon Energy Inc. of El Paso, Texas; and Solar Cells Inc. of Toledo, Ohio.

Siemens Solar Industries, as previously stated, is currently the world's largest producer of PV products based on crystalline silicon. Siemens also has a major research activity in thin film CuInSe $\mathrm{C}_{2}$ modules, for which they have a planned production of $20 \mathrm{~kW}$ in deliverable modules under the PVUSA project. Siemens research under Phase 1 of PVMaT identified several problem areas for improving their process. Among these are improving the efficiency of materials usage increasing yield and $\mathrm{CuInSe}_{2}$ module efficiency through automation.

Boeing supplies thin-film solar cell manufacturing systems and conducts research on the development and scaleup of processing for CuInGaSe ${ }_{2}$ modules. Boeing research under Phase 1 of PVMaT identified several problem areas for improving their process. These include uniform large-scale evaporation sources for the constituent elements $\mathrm{Cu}, \mathrm{In}, \mathrm{Ga}$, and Se; a high-yield process for depositing ultra-thin cadmium zinc sulfide $(\mathrm{CdZnS})$ conformal coatings onto $\mathrm{CuInGaSe}_{2}$ films for high-quality heterojunctions; and scaling up current aqueous deposition processes and novel low-temperature organometallic chemical vapor deposition techniques.

Two companies are investigating improvements to CdTe technology. Photon Energy manufactures $\mathrm{CdTe} / \mathrm{CdS}$ cells and modules using low-cost, high-throughput, production-line scalable spray processes. Photon Energy is currently preparing for the production of $20 \mathrm{~kW}$ of $4-\mathrm{ft}^{2} \mathrm{CdTe}$ module deliverables under the PVUSA project. Photon Energy research under Phase 1 of PVMaT identified several problem areas for improving their process. These include reducing labor costs through process automation, improving module efficiency, and reducing material usage through improved equipment designs.

Fourth in the thin-film group and the second CdTe company is Solar Cells Inc., which is a development/manufacturing company producing large-area, thin-film PV modules for utility generating systems. They are developing the technology for a high-throughput manufacturing line to produce $60 \mathrm{~cm}$ x $120 \mathrm{~cm}$ thin-film CdTe PV modules deposited by close-spaced sublimation. Solar Cells research under Phase 1 of PVMaT identified several problem areas for improving their process. These include investigating problems associated with uniform deposition of large-area modules, developing equipment for very high throughput deposition, developing patterning techniques for large-area modules, and developing cost-effective encapsulation techniques.

\section{Concentrators}

Concentrator modules use lenses to focus and intensify the sunlight falling on banks of small, highly efficient cells. Thus, smaller cell areas are required in concentrating modules and cell material costs are substantially reduced. $R \& D$ issues include optimum cell packaging and assembly, concentrator optics, and low-cost tracking arrays and support structures. Manufacturing cost reductions would occur primarily through automated assembly. 
The six concentrator companies working in this area include Alpha Solarco Inc. of Cincinnati, Ohio; Solar Engineering Applications Corp. of San Jose, Califomia; Kopin Corporation of Taunton, Massachusetts; Entech Inc. of Dallas, Texas; Spectrolab Inc. of Sylmar, California; and Solar Kinetics, Inc. of Dallas, Texas.

Alpha Solarco Inc. manufactures high-concentration PV modules. They are currently installing a secondgeneration system on the world's largest automated two-axis solar tracking structure to produce low-cost electric power for utilities. Alpha Solarco research under Phase 1 of PVMaT identified several problem areas for improving their process. These include developing and testing new manufacturing designs, methods, and materials for cell assembly and PV modules; designing a prototype automated PV cell assembly line; and developing production controls and training procedures for prototype lines.

Solar Engineering Applications Corp. manufactures 10X concentrator systems using one-sun cells with a $14 \mathrm{MW} / \mathrm{yr}$ extruded lens manufacturing facility in place. Research under Phase 1 of PVMaT identified several problem areas for improving their process. These include investigating the problems associated with, and the potential of, adding module housing sides to lens extrusions; and significantly reducing labor costs through process automation.

Kopin Corporation manufactures high-efficiency thin-film GaAs concentrator cells with a $22 \mathrm{MW} / \mathrm{yr}$ prototype production capability currently in place. Kopin research under Phase 1 of PVMaT identified several problem areas for improving their process. These include designing a tandem cell structure for $1000 \mathrm{X}$ concentrators, improving thin-film cell processing manufacturing, and integrating into their cell fabrication process either a chemical removal process called chemical epitaxial liftoff or the cleavage of lateral epitaxy for transfer (CLEFT) process.

Entech Inc. manufactures concentrator modules. Entech is currently producing $3 \mathrm{ft} \mathrm{x} 10 \mathrm{ft}$ modules using one-sun cells with line-focus Fresnel lenses. Entech's research under Phase 1 of PVMaT identified several problem areas for improving their process. These include working with key vendors to improve the products they supply to Entech, and dramatically reducing labor costs and increasing yield by process automation.

Spectrolab Inc. is a leading supplier of GaAs and Si solar cells and panels to the PV industry. Spectrolab research under Phase 1 of PVMaT identified several problem areas for improving their process. These include optimizing two specific multijunction concentrator designs based on discrete GaAs and Ge cells, improving manufacturing yields, and developing larger, more efficient metal-organic chemical vapor deposition growth systems.

The sixth company working on concentrator technology, Solar Kinetics, manufactures crystalline-silicon concentrator systems with a 200-600 kW/yr capacity. Solar Kinetics research under Phase 1 of PVMaT identified several problem areas for improving their process. These include designing and developing prototype tooling for demonstrating low-cost injection molding of point-focus Fresnel lenses, producing detailed designs of a 1-MW plant, and producing a detailed plant design for 5-MW capacity for automated manufacturing of $100-\mathrm{W}$ concentrating PV modules.

\section{Other Phase 1 Activities}

Two Phase 1 participants are targeting improvements to their commercial lines of manufacturing equipment. This diversified group includes Global Photovoltaic Specialists Inc. of Canoga Park, Califomia; and Spire Corporation of Bedford, Massachusetts. 
Global Photovoltaic Specialists Inc. is a PV technology company that provides the equipment and knowhow for integrated tumkey factories. They are presently investigating the installation of a fully automated, computer-integrated production line in the United States. Research under Phase 1 of PVMaT identified several problem areas for improving their process. These include improving the characteristics of the semicrystalline cast wafers; introducing processes such as spray-on diffusion, dual antireflective coatings, and ink-jet metallization printing; and developing and integrating all of the requirements for full automation using computer integrated manufacturing.

Spire Corporation is a major manufacturer of PV test and module production equipment. Spire currently has small-scale production activities for high-efficiency silicon modules and conducts material research in compound semiconductors and a-Si. Spire research under Phase 1 of PVMaT identified several problem areas for improving their process. These include developing module processing equipment that will handle thin $(<200 \mu \mathrm{m})$ crystalline-silicon wafers, increasing automation, increasing processing rates, and increasing processing yields. 